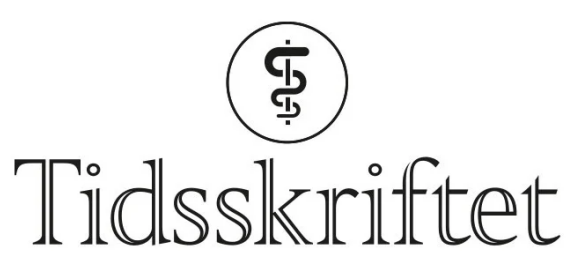

DEN NORSKE LEGEFORENING

\title{
Klimakrisen: Helsevesenet må ta ansvar
}

\section{LEDER}

\section{ANAND BHOPAL}

anand.bhopal@uib.no

Anand Bhopal er lege og stipendiat ved Bergen senter for etikk og prioritering, Universitetet i Bergen. Han er leder av Grønt Helsevesen.

Forfatteren har fylt ut ICMJE-skjemaet og oppgir ingen interessekonflikter.

\section{SOFIE HAUGAN SHRIVASTAVA}

Sofie Haugan Shrivastava er medisinstudent ved Universitetet i Bergen og styremedlem av Grønt Helsevesen.

Forfatteren har fylt ut ICMJE-skjemaet og oppgir ingen interessekonflikter.

\section{Helsesektoren står for en betydelig andel av Norges klimagassutslipp. Vi trenger en grønn omstilling nå.}

Klimaendringer er utbredte, omfattende og i hurtig utvikling. For å nå Parisavtalens mål kreves en umiddelbar reduksjon av klimagassutslipp, ifølge den nyeste advarselen fra FNs klimapanel (1). Globalt står klimagassutslippene fra helsesektoren for mer utslipp enn flytrafikk og shipping til sammen (므). Det norske helsevesenet er blant de mest utslippsintensive i verden målt per innbygger, og 4,3\% av Norges klimagassutslipp kommer fra helsesektoren (3,4). Vi er altså et svært godt eksempel på at det er en omvendt korrelasjon mellom helsevesenets karbonavtrykk og befolkningens behov for helsehjelp: Landene med de laveste utslippene har også de høyeste uoppfylte helsebehovene - og høyest risiko for katastrofale konsekvenser av klimaendringer (5). Fattigere land kan ikke forventes å kutte sine klimagassutslipp på bekostning av helsehjelp. Det ansvaret hviler på de ressurssterke landene, som også står for de høyeste utslippene.

«Globalt står klimagassutslippene fra helsesektoren for mer utslipp enn flytrafikk og shipping til sammen»

Det engelske helsevesenet, NHS, har nylig vedtatt en nasjonal plan for å nå nullutslippsmålet innen 20 år (ㅁ), og har 150 ansatte som jobber med dette. Klimarapporten fra den engelske helsesektoren viser at det er mulig å levere gode helsetjenester og samtidig redusere klimagassutslippene. Rapporten fra FNs klimapanel 
understreker at klimaendringene er svært utbredte, raske og selvforsterkende (1). Det vil si at vi ikke kan bruke 20 år på å nå nullutslippsmålet om vi skal holde temperaturene innen Parisavtalens mål. Selv ved å følge dagens implementerte internasjonale klimaforpliktelser vil vi få en verden som er $2,7-3,1^{\circ} \mathrm{C}$ varmere innen 2100 , noe som vil endre jorda til det ugjenkjennelige (7.). For å bidra til å unngå katastrofale klimaendringer er Norge nødt til å være mer ambisiøse og utvikle fremtidens lavkarbonløsninger for helsesektoren.

Helsesektoren i Norge har til nå i stor grad vært distansert fra den politiske innsatsen for å takle klimaendringer. Men nå er vi nødt til å tenke nytt om måten vi drifter helsevesenet på. Vi som helsearbeidere må bidra til å redusere utslipp fra helsesektoren og å kartlegge veien mot en mer bærekraftig og karbonfattig verden.

Klinikere kan bidra til å kutte utslipp på flere måter. Vi bør ha en bærekraftig tilnærming til kliniske løsninger $(\underline{8})$ og etablere grønne nettverk innen våre spesialiteter. Men selv om vi kan iverksette gode tiltak lokalt, er mange av de nødvendige tiltakene utenfor kontrollen til den enkelte helsearbeider. Rundt $70 \%$ av helsevesenets karbonavtrykk kommer fra utslipp innebygd i globale helseforsyningskjeder som produksjon, emballasje, transport og avfallhåndtering av tjenester og utstyr (9). Legemidler står alene for 20 \% av disse utslippene (5). Det er nettopp her kuttene må gjøres, og vi trenger beslutningstakerne med oss på laget.

\section{«Nå er vi nødt til å tenke nytt om måten vi drifter helsevesenet på»}

Utslippene fra den norske helsesektoren må kuttes, og det må skje raskt. Nylig ble det ble fremmet et forslag i Stortinget om å lage en klimaplan for helsesektoren (므). Dette var et skritt i riktig retning, men dessverre ble forslaget nedstemt. Det illustrerer at Norge og norske politikere er for lite ambisiøse og for lite handlingsrettede. En fremtidig klimanøytral helsesektor er mulig, med de rette ambisjoner samt konkrete nasjonale og koordinerte planer. Å utvikle en vei mot lavkarbonhelsetjenester er helt essensielt for å stoppe økende utslipp fra den globale helsesektoren i årene som kommer. Løsningene er mange og finnes allerede $(5, \underline{6})$. Det krever ikke bare politisk vilje - det krever politisk handling.

Gjennom satsning på en grønn omstilling i helsesektoren følger man et viktig medisinsk prinsipp: Det er bedre å forebygge enn å helbrede. Vi håper både velgerne ved stortingsvalget i høst og de nye folkevalgte anerkjenner klimakrisen som en helsekrise og tar dette på alvor. Med ansvar for både helsen og kloden til fremtidige generasjoner er vi nødt til å handle $n a ̊ !$

\section{LITTERATUR}

1. Summary for Policymakers. I: Climate Change 2021: The Physical Science Basis. Contribution of Working Group I to the $6^{\text {th }}$ Assessment Report of the IPCC. Cambridge: IPCC, Cambridge University Press, 2021. https://www.ipcc.ch/report/ar6/wg1/ Lest 9.8.2021.

2. World in Data. Sector by sector: where do global greenhouse gas emissions come from? https://ourworldindata.org/ghg-emissions-by-sector Lest 24.6.2021.

3. Brean A. Helseskadelige helseutslipp. Tidsskr Nor Legeforen 2020; 140. doi: 10.4045/tidsskr.20.0830. [PubMed][CrossRef]

4. Healthcare Without Harm. Global Road Map for Healthcare Decarbonisation: Norway Fact Sheet. https://healthcareclimateaction.org/fact-sheets/77 Lest 1.7.2021.

5. Watts N, Adger WN, Agnolucci P et al. Health and climate change: policy responses to protect public health. Lancet 2015; 386: 1861-914. [PubMed][CrossRef]

6. Greener NHS. Delivering a 'Net Zero' National Health Service. London: National Health Service, 2020. https://www.england.nhs.uk/greenernhs/publication/delivering-a-net-zero-national-healthservice/ Lest 24.6.2021. 
7. Climate Action Tracker. The CAT Thermometer. https://climateactiontracker.org/global/catthermometer/Lest 9.8.2021.

8. Mortimer F, Isherwood J, Wilkinson A et al. Sustainability in quality improvement: redefining value. Future Healthc J 2018; 5: 88-93. [PubMed][CrossRef]

9. Karliner J, Slotterback S. Health Care's Climate Footprint. Health Care Without Harm, 2019. https://noharm-global.org/climatefootprintreport Lest 9.8.2021.

10. Representantforslag om å utarbeide en klimaplan for helsesektoren. Dokument 8:143 S (20202021), Innst. $472 \mathrm{~S}$ (2020-2021). https://stortinget.no/no/Saker-og-publikasjoner/Saker/Sak/?p=83884 Lest 9.8.2021.

Publisert: 31. august 2021. Tidsskr Nor Legeforen. DOI: 10.4045/tidsskr.21.0578

(C) Tidsskrift for Den norske legeforening 2023. Lastet ned fra tidsskriftet.no 26. april 2023. 